\title{
Studi Numerik Karakteristik Aliran Melalui Backward Facing Inclined Step dengan Penambahan Paparan Panas Deri Gedung pada Sisi Upstream
}

\author{
Franciska Enstinita Puspita dan Wawan Aries Widodo \\ Departemen Teknik Mesin, Fakultas Teknologi Industri, Institut Teknologi Sepuluh Nopember \\ e-mail: wawanaries@me.its.ac.id
}

\begin{abstract}
Abstrak-Studi ini bertujuan untuk melihat karakteristik aliran fluida yang melalui backward facing inclined step dengan penambahan paparan panas dari high rise building pada sisi upstream. Peninjauan dilakukan dengan menggunakan perangkat lunak CFD (Computational Fluid Dynamic). Pemodelan ini menggunakan aliran steady flow, incompressible flow, dan uniformflow pada sisi inlet. Simulasi ini menggunakan model turbulen $k$ - $\omega S S T$ dengan kecepatan angin pada inlet $3 \mathrm{~m} / \mathrm{s}$ dan 9 $\mathrm{m} / \mathrm{s}\left(\operatorname{Re}=2 \times 10^{4}\right.$ dan $\left.\operatorname{Re}=6 \times 10^{4}\right)$. Meshing menggunakan Hexahedral dengan jumlah node $2,5 \times 10^{6}$. Variasi inclined step $30^{\circ}, 4^{\circ}$, dan $90^{\circ}$. Kecepatan fluida panas dari gedung yaitu $1,5 \mathrm{~m} / \mathrm{s}$ dengan temperatur $64^{\circ} \mathrm{C}$. Angin lingkungan memiliki temperatur $27^{\circ} \mathrm{C}$. Hasil yang didapatkan dari penelitian ini adalah variasi sudut inclined step mempengaruhi kecepatan fluida, panjang reattachment, dan luas wilayah yang mengalami kenaikan temperatur. Perbandingan kontur kecepatan memperlihatkan luas area backflow paling sempit berada pada inclined step $30^{\circ}$. Pada pathline tiap variasi inclined step diketahui bahwa reattachment paling pendek berada pada model dengan sudut inclined step $30^{\circ}$. Berdasarkan kontur pada posisi $\mathrm{y} / \mathrm{h}=0,5$ dan $\mathrm{y} / \mathrm{h}=1$ pada daerah downstream, persebaran temperatur paling sempit ada pada domain dengan sudut inclined step $30^{\circ}$. S elain itu variasi bilangan Reynolds juga berpengaruh terhadap persebaran temperatur. Semakin tinggi nilai bilangan Reynolds maka semakin kecil kenaikan temperatur lingkungan yang terjadi.
\end{abstract}

Kata Kunci-high rise building, inclined step, paparan panas, velocity profile, temperature contour.

\section{PENDAHULUAN}

$\mathrm{I}$ NDONESIA memiliki kekayaan budaya dan keindahan alam yang menarik bagi wisatawan. Perlu adanya dukungan terhadap daerah wisata berupa akses ke tempat wisata, transportasi, dan penginapan. Adanya pembangunan fasilitas tersebut mempengaruhi lingkungan sekitarnya, terutama pembangunan penginapan. Metode numerik untuk menganalisa hubungan antara pembangunan dan lingkungan merupakan alat untukengineer, arsitek, perencanaan kota, dan kebijakan public untuk menggabungkan desain perkotaan alternatif dan untuk membuat kebijakan pedoman. CFD adalah salah satu alat dari metode numerik tersebut, yang sering digunakan pada iklim perkotaan dalam berbagai skala [1]. Pada simulasi angin lingkungan, biasanya menggunakan model turbulen. Terdapat lebih dari satu jenis model turbulen pada CFD. Dari 11 turbulen model, kontur dari turbulen model dengan grup yang sama memiliki hasil yang mirip [2].
Variasi dari simulasi dapat berupa bentuk domain. Dimana pada kenyataanya wilayah yang memiliki kondisi tanah yang rata hanya sebagian kecil. Domain dapat berupa enlargement yang memiliki backwardfacing incined step. Step dari domain pun memiliki sudut yang bervariasi. Semakin kecil sudut inclined step makan semakin pendek jarak titik reattachment dengan step [3]. Namun apabila sudut inclined step terlalu kecil makan panjnag reattachment tidak dapat terukur pada eksperimen [3].

Hasil dari penelitian aliran fluida yang melewati backward facing inclined step dengan penambahan paparan panas dari gedung pada sisi upstream adalah mendapatkan data pedukung yaitu data kuantitatif dan data kulitatif. Data kuantitatif berupa grafik distribusikoefisien tekanan (Cp), skin friction coefficient (Cf), dan jarak reattachment pada darah downstream. Data kualitatif (visualisasi aliran) antara lain berupa kontur kecepatan, kontur tekanan, dan pathline dari vektor kecepatan.

\section{PENELITIAN}

\section{A. Urban Microclimate}

Urban Microclimate semakin populer terutama di negaranegara maju sebab urbanisasi yang cepat. Beberapa dokumentasi studi Urban Microclimate membahahas tentang konsumsi energi gedung, kondisi kesehatan dan kualitas hidup manusia, tingkat harapan hidup, dan temperatur yang nyaman untuk hidup. Sebagian besar penelitian urban microclimate, baik eksperimen maupun simulasi, dilakukan pada bidang datar. Hal ini dikarenakan fokus pada penelitian adalah perkotaan dimana sebagian besar wilayahnya datar. Namun sekarang pembangunan telah sampai ke berbagai wilayah. Termasuk pedesaan maupun pinggiran kota. Pemandangan yang masih alami menjadikan bangunan modern memiliki nilai jual tersendiri. Selain itu, pembangunan dilakukan pada daerah yang lebih tinggi dari sekitarnya. Hal ini akan membuat para penghunimendapatkan pemandangan terbaik apabila bangunan berada lebih tinggi dari sekitarnya. Tidak menutup kemungkinan bahwa daerah di bawah bangunan tersebut akan semakin padat. Maka itu diperlukan penelitian urban microclimate dan $C F D$ hadir untuk membantu memberikan simulasi pada permasalahan urban microclimate.

\section{B. Geometri Benda Uji}

Penelitian secara numerik ini dilakukan dengan menyimulasikan model (gambar 1) dengan backward facing 
inclined step dengan penambahan gedung pada bagian upstream. Referensi $\mathrm{y} / \mathrm{h}=0$ berada pada sisi inlet $\mathrm{yang}$ sejajar dengan wall bawah (gambar 3).

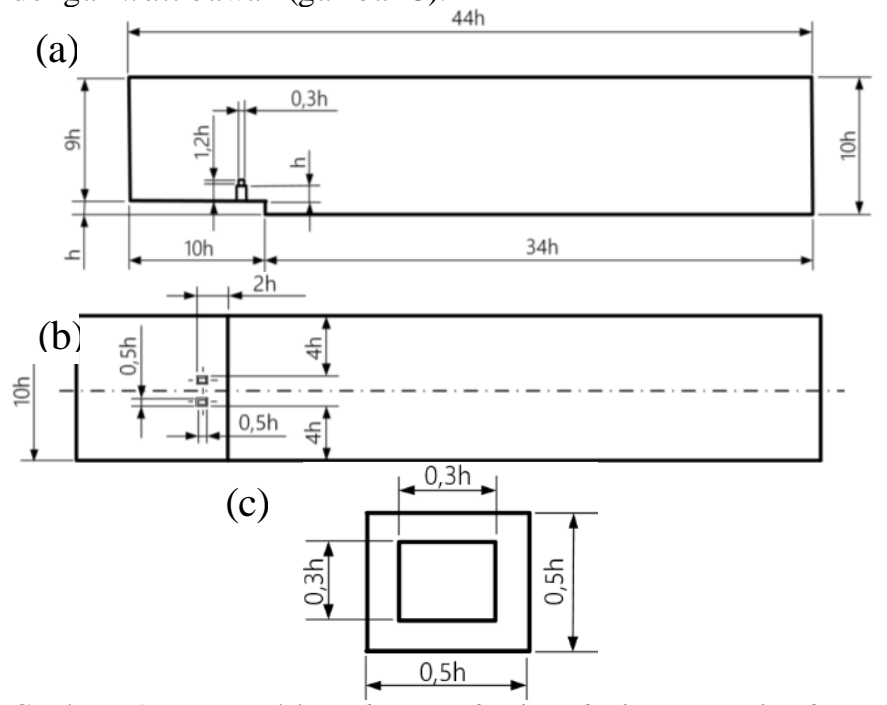

Gambar 1. Permodelan domain backward facing inclined step (a) tampak samping;(b) tampak at as; dan (c) dimensi kondensor (bawah).

Spesifikasi dari domain adalah sebagai berikut:
- Tinggi Step
$=\mathrm{h}$
- Panjang sisi upstream
$=10 \mathrm{~h}$
- Panjang sisi downstream
$=34 \mathrm{~h}$
- Tinggi inlet
$=9 \mathrm{~h}$
- Tinggi outlet
$=10 \mathrm{~h}$
- Lebar geometri penampang $=10 \mathrm{~h}$

Dimensi Gedung dan kondensor

- Tinggi gedung $=\mathrm{h}$

- Lebar gedung $=0.5 \mathrm{~h}$

- Panjang gedung $=0.5 \mathrm{~h}$

- Tinggi area kondensor $\quad=0.2 \mathrm{~h}$

- Lebar area kondensor $\quad=0.3 \mathrm{~h}$

- Panjang area kondensor $=0.3 \mathrm{~h}$

Variasi yang akan dibuat pada model adalah sudut backward inclined step $(\alpha)$, yaitu: $30^{\circ}, 45^{\circ}$, dan $90^{\circ}$. Kemudian dilakukan pula variasi kecepatan inlet, yaitu $3 \mathrm{~m} / \mathrm{s}\left(\mathrm{Re}=2 \times 10^{4}\right)$ dan $9 \mathrm{~m} / \mathrm{s}$ $\left(\operatorname{Re}=6 \times 10^{4}\right)$.

\section{C.Metode Numerik}

Penelitian ini adalah dengan menyimulasikan proses fluida melewati domain sehingga dari penelitian ini dapat diketahui kecepatan fluida dan kenaikan temperatur pada bagian downstream. Penyimulasian pada penelitian ini memanfaatkan komputasi fluida (CFD) untuk melakukan pendekatan secara numerik dan membuat geometri model. Pada pemodelannya, model dibuat sedemikian rupa hingga menjadi seperti geometri pada gambar 2 serta mendiskritisasikan model (meshing) yang rapat pada dinding sehingga model dapat diproses dengan CFD. Secara umum, urutan kerja yang dilakukan pada penelitian numerik ada dua tahapan, yaitu tahap pre-processing dan dilanjutkan dengan tahap post-processing.

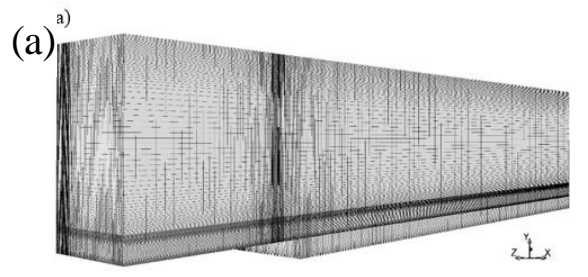

(b) b)

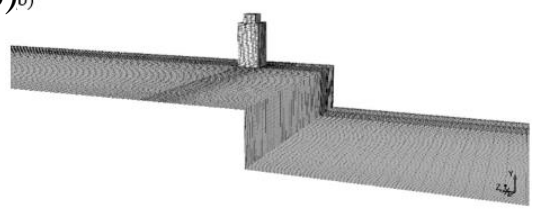

Gambar 2. Tahap Pre-processing (a) rapat dekat wall, (b) rapat dekat gedung.

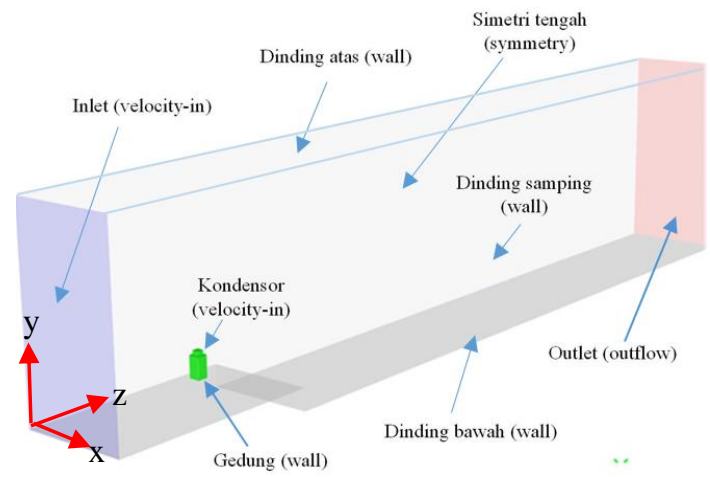

Gambar 3. Boundary Condition.

\section{D.Pengambilan Data}

Pengambilan hasil setelah dilakukan iterasi. Hasil tersebut berupa data kuantitatif dan kualitatif. Data kuantitatif berupa distribusinilai kecepatan, temperatur, Cp dan Cf. Data kualitatif berupa penampilan pathline velocity profile, kontur kecepatan, dan kontur temperatur serta variasi-variasi yang digunakan pada penelitian ini.
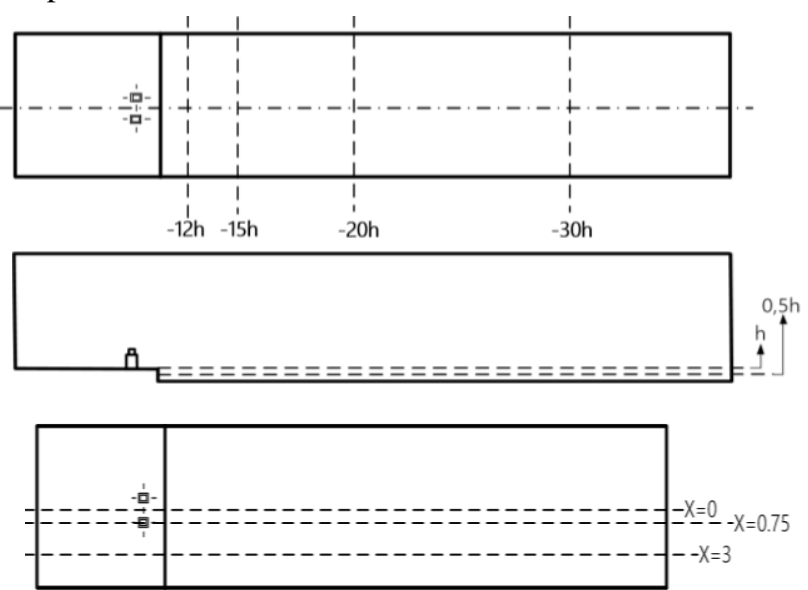

Gambar 4. Posisi pengambilan data (a) kecepatan dan temperatur; (b) temperatur; (c) $\mathrm{Cp}, \mathrm{Cf}$, jarak reattachment, kecepatan, dan temperatur.

Selain itu, untukmenunjang data kualitatif kontur kecepatan dan kontur temperatur diperlukan data kuantitatif. Data kuantitatif dipresentasikan dalam bentuk grafik. Adapun pengambilan grafik kecepatan ditampilkan pada Gambar 5c pada posisi $\mathrm{x} / \mathrm{h}=0,75$ (melewati gedung) dan sudut inclined step $30^{\circ}\left(\mathrm{Re}=2 \times 10^{4}\right)$. Data grafik kecepatan diambil dari posisi $\mathrm{y} / \mathrm{h}=0 \quad$ sampai $\mathrm{y} / \mathrm{h}=2,2 \quad$ di titik $\mathrm{z} / \mathrm{h}=-12$, 
$-15,-20$, dan -30 . Pengambilan data grafik distribusi temperatur ditampilkan pada Gambar 4b. Pada $\mathrm{Cp}$ dan $\mathrm{Cf}$ diambil pada wall bawah sepanjang downstream seperti ditunjukkan pada Gambar 4c. Sedangkan kontur kecepatan diambil pada posisi gambar $4 a$ dan $4 c$. Kontur temperatur diambil pada semua posisi pada gambar 4. Pathline kecepatan diambil pada posisigambar $4 \mathrm{c}$.

\section{E. Grid Independency}

Analisa grid independency menggunakan model turbulen dengan menganalisa kecepatan rata-rata (Vavg) untuk setiap variasi mesh yang dibuat pada posisi $\mathrm{z} / \mathrm{h}=-8$ dengan sudut inclined step $90^{\circ}$, sehingga dapat dilihat pada tabel 1 .

Tabel 1.

Grid independency ditinjau dari kecepatan rata-rata pada cross section $\mathrm{z} / \mathrm{h}=-8$.

\begin{tabular}{cccc}
\hline \hline Mesh & $\begin{array}{c}\text { Jumlah node } \\
\text { (juta) }\end{array}$ & Kecepatan rata-rata (m/s) & Error $(\%)$ \\
\hline Mesh A & 1,5 & 2,9284 & - \\
Mesh B & 2 & 2,9381 & 1,04 \\
Mesh C & 2,5 & 2,9376 & 0,05 \\
Mesh D & 3 & 2,9370 & 0,06 \\
\hline \hline
\end{tabular}

Dari hasil grid independency yang telah dilakukan diperoleh variasi kerapatan mesh yang tidak terdapat perubahan secara signifikan yaitu pada variasi mesh tiga dengan jumlah mesh nodes sebesar 2,5 juta nodes. Selain itu, untuk memperjelas hasil dari grid independency dibuatlah suatu grafik yang menunjukan hubungan antara jumlah node dan kecepatan ratarata.

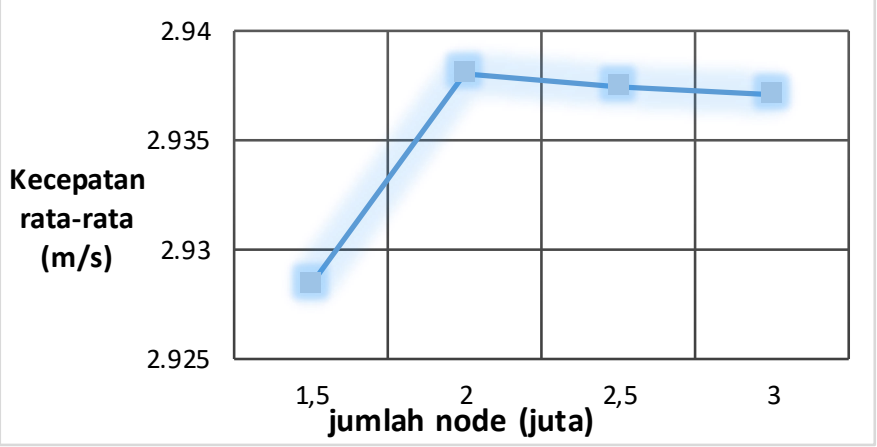

Gambar 5. Grid independency kecepatan ditinjau pada $\mathrm{z} / \mathrm{h}=-8$.

\section{HASIL DAN DISKUSI}

\section{A. Variasi Sudut Backward Facing Inclined Step}

Distribusi kecepatan aliran fluida yang melewati gedung dengan variasi sudut inclined step memiliki grafik yang sama. Gambar garfik 6 yang diambil dari bebrapa titik pada daerah downstream memperlihatkan bentuk grafik yang sama. Grafik pada $\mathrm{z} / \mathrm{h}=-12$ terlihat penurunan kecepatan akibat adanya backflow kemudian kecepatan berangsur-angsur normal. Apabila data diambil lebih jauh dari step, pada titik $\mathrm{z} / \mathrm{h}=-15$, maka akan terlihat pengaruh backflow tidak sebesar pada titik $\mathrm{z} / \mathrm{h}=-12$. (a)

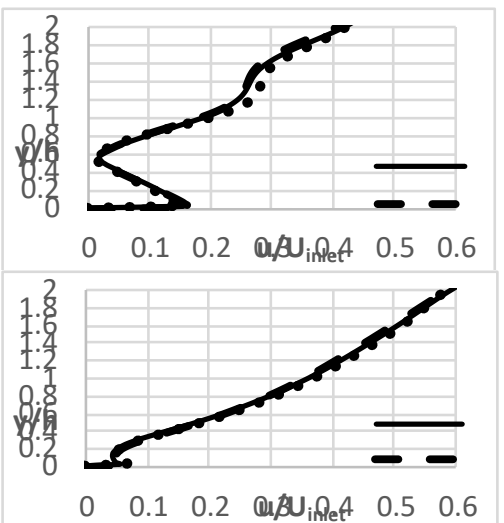

Gambar 6. Perbandingan profil kecepatan $\{\mathrm{u} /$ Uinlet $)$ dengan variasi sudut incined step pada posisi $\mathrm{x}=0,75\left(\mathrm{Re}=2 \times 10^{4}\right) ;(\mathrm{a}) \mathrm{z} / \mathrm{h}=-12 ;$ (b) $\mathrm{z} / \mathrm{h}=-15$.

Gambar 7 memperlihatkan perubahan warna yang mewakili perubahan kecepatan. Nilai kecepatan dari setiap warna dapat dilihat pada skala warna. Warna biru pada kontur mengindikasikan adanya backflow.
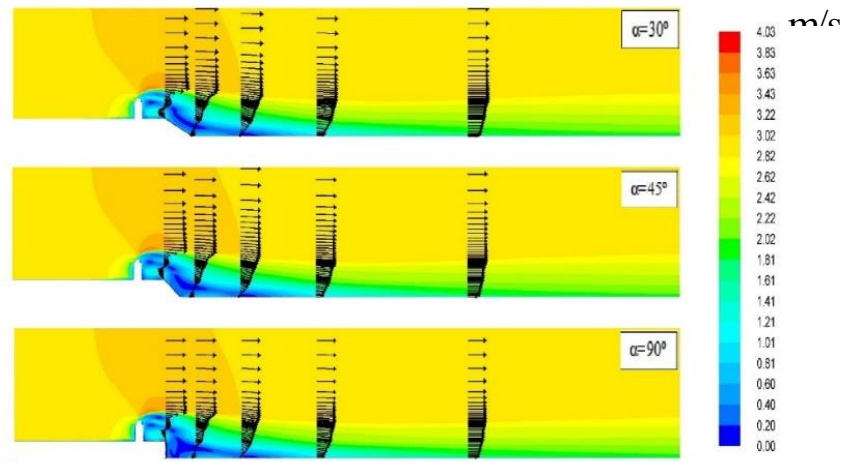

$z_{s} \cdot Y_{t}^{+}$

Gambar 7. Visualisasi kont ur kecepatan dengan variasi sudut inclined step pada posisi $\mathrm{x}=0,75\left(\operatorname{Re}=2 \times 10^{4}\right)$.

Perbandingan kecepatan setiap variasi step juga dapat dilihat pada gambar 8 dimana terdapat perbedaan luas area backflow.

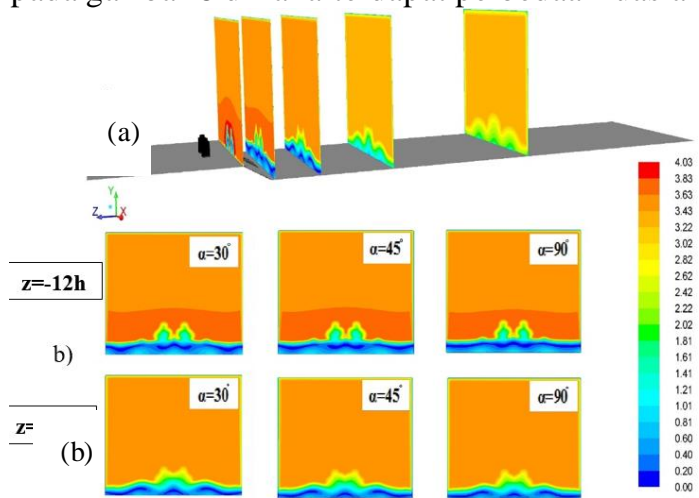

Gambar 8. (a) Visualisasi aliran 3d kontur velocity magnitude dengan sudut inclined step $30^{\circ}$ dan (b) Perbandingan velocity magnitude pada $\mathrm{z}=-12 \mathrm{~h}$ dan $\mathrm{z}=-$ $15 \mathrm{~h}\left(\mathrm{Re}=2 \times 10^{4}\right)$

Pada gambar 9, perbandingan kontur kecepatan pada variasi bilagan Reylonds memiliki hasil yang sama. Domain dengan step $\alpha=30^{\circ}$ memiliki area backflow yang lebih sempit dari pada domain dengan sudut step lainnya. 

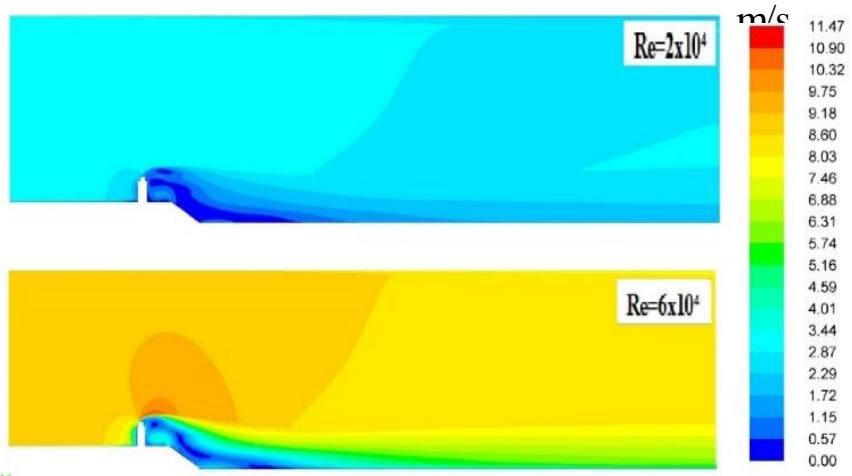

$z_{i} \cdot \dot{x}$

Gambar 9. Perbandingan profil kecepatan dengan variasi Reynolds number pada posisi $x=0,75\left(\alpha=30^{\circ}\right)$.

Variasi sudut inclined step juga berpengaruh terhadap jangkauan kenaikan temparatur akibat paparan panas dari gedung. Jangkauan kenaikan temperatur terjauh ada pada domain dengan $\alpha=90^{\circ}$. Hal tersebut terlihat pada gambar 10 dan 11. Gambar 10 dan 11 merupakan kontur temperatur pada daerah downstream. Gambar 12 adalah grafik perbandingan temperatur lokal dengan tempratur inlet pada daerah downstream.
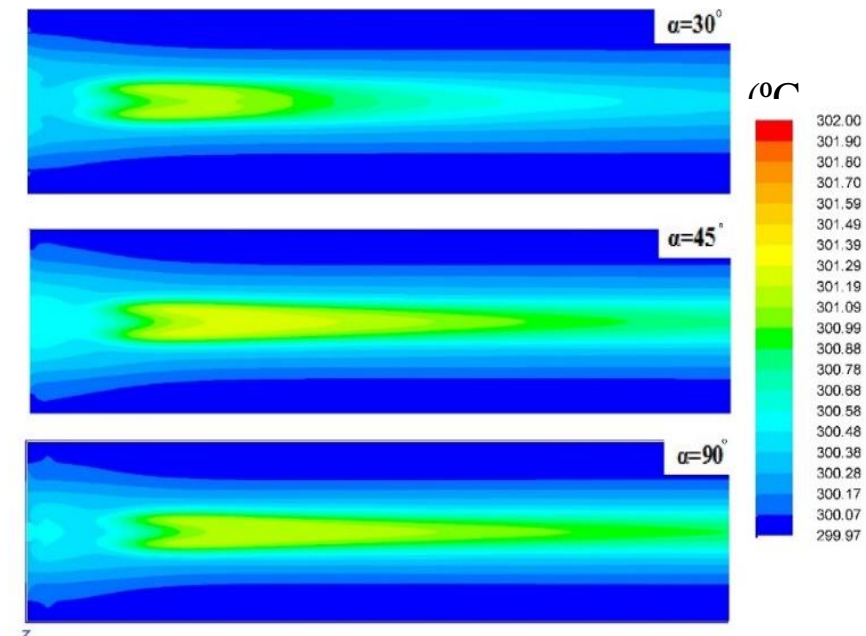

$x+\frac{7}{1}$

Gambar 10. Kontur temperatur pada posisi $\mathrm{y} / \mathrm{h}=0,5\left(\mathrm{Re}=2 \times 10^{4}\right)$.
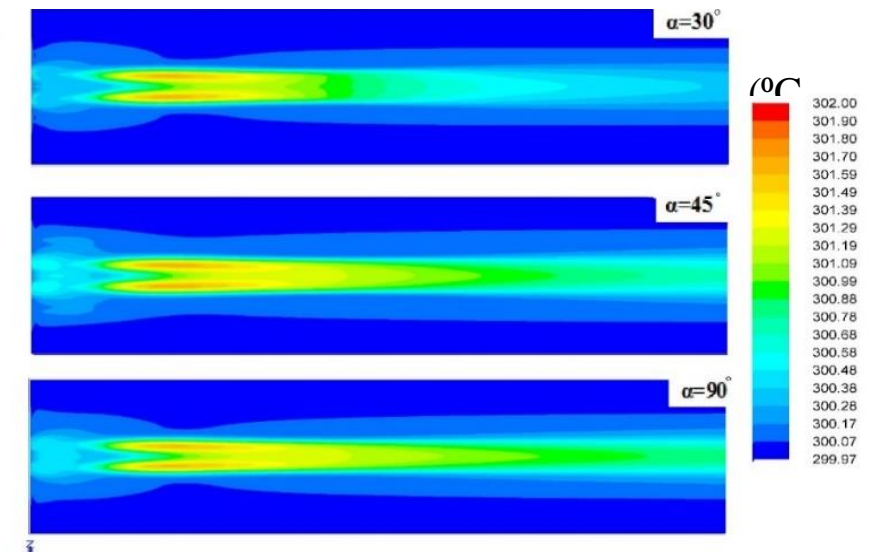

Gambar 11. Kontur temperatur pada posisi $\mathrm{y} / \mathrm{h}=1\left(\mathrm{Re}=2 \times 10^{4}\right)$. (a)

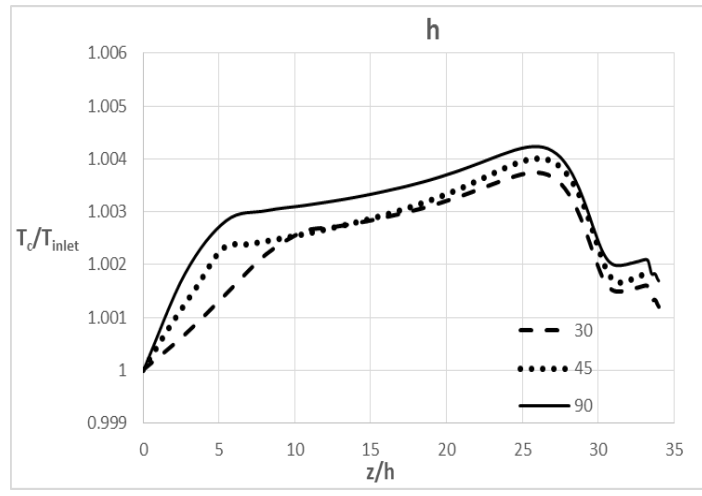

(b)

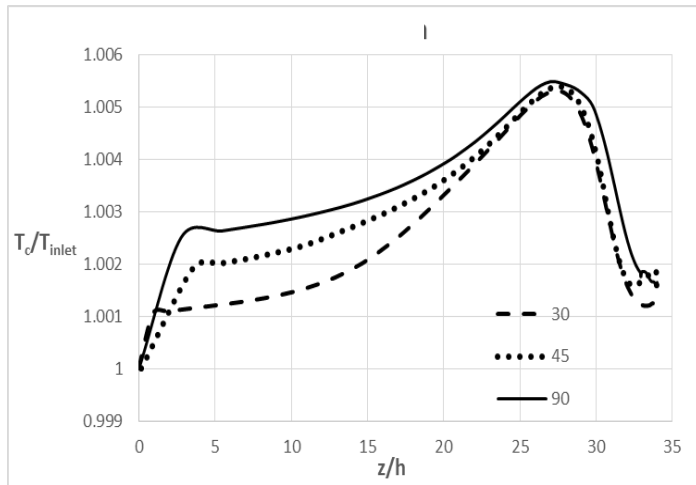

Gambar 12. Grafik distribusi temperatur sepnjang $\mathrm{z} / \mathrm{h}$ pada $\mathrm{x}=0,75\left(\mathrm{Re}=2 \times 10^{4}\right)$; (a) $y / h=0,5 ;(b) y / h=1$.

Gambar kontur diambil pada plane $\mathrm{y} / \mathrm{h}=0,5$ dan $\mathrm{y} / \mathrm{h}=1$ atau setinggistep. Pada Gambar 10 terlihat jelas adanya peningkatan temparatur di sepanjang sumbu z sampai di outline. Pada $\alpha=30^{\circ}$ terlihat bahwa kenaikan temperatur bisa mencapai $1,18^{\circ} \mathrm{C}$. Namun area pada temperatur ini lebih sempit dari pada sudut step yang lain. Jangkauan kenaikan temperatur terjauh berada pada downstream dengan $\alpha=90^{\circ}$. Gambar 11, jika ketinggian plane kemudian dinaikan menjadi sejajar dengan step maka akan didapatkan gambaran yang serupa. Dimana area kenaikan temperatur tertinggi, yaitu sekitar $1,64^{\circ} \mathrm{C}$, paling luas berada pada domain yang memiliki sudut inclined step $90^{\circ}$. Dari gambar 12 menunjukan perbandingan kenaikan temperatur local terhadap temperatur inlet mencapai $1,0042(\mathrm{y} / \mathrm{h}=0.5)$ dan $1,0055(\mathrm{y} / \mathrm{h}=1)$.

Area terjauh yang mengalami kenaikan temperatur berada pada $\alpha=90^{\circ}$ sedangkan area tersepit berada pada $\alpha=30^{\circ}$. Hal ini karena fluida panas dari gedung terjebak pada wake akibat adanya englagement. Pada domain $\alpha=90^{\circ}$ memiliki wake yang lebih luas areanya sehingga fluida panas dari gedung lebih lama terjebak pada daerah downstream. Sedangkan pada domain $\alpha=30^{\circ}$ memiliki wake yang lebih sempit sehingga fluida panas yang terjebak juga lebih sedikit. Hal ini membuat area kenaikan temperatur tidak begitu luas dari pada domain lainnya.

Pada profil temperatur, perbedaan kecepatan aliran fluida mempengaruhi transfer panas ke lingkungan sekitarnya. Secara teori, semakin kencang laju aliran fluida maka semakin dingin temperatur lingkungan sebab tidak terjadi penumpukan panas pada daerah downstream. 


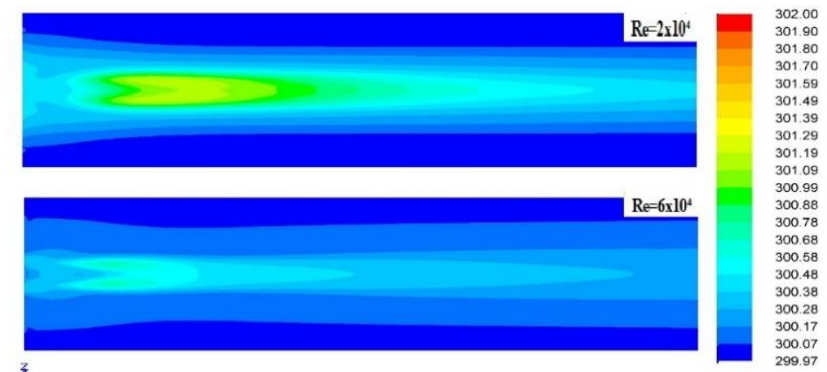
等

Gambar 13. Perbandingan visualisasi kontur temperatur dengan variasi Reynolds number pada posisi $y / h=1$ dan $\alpha=30^{\circ}$.

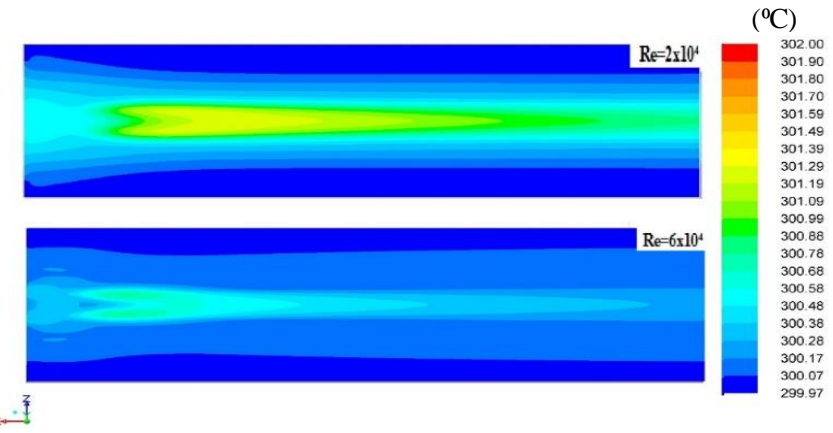

Gambar 14. Perbandingan visualisasi kontur temperatur dengan variasi Reynolds number pada posisi $\mathrm{y} / \mathrm{h}=1$ dan $\alpha=45^{\circ}$.

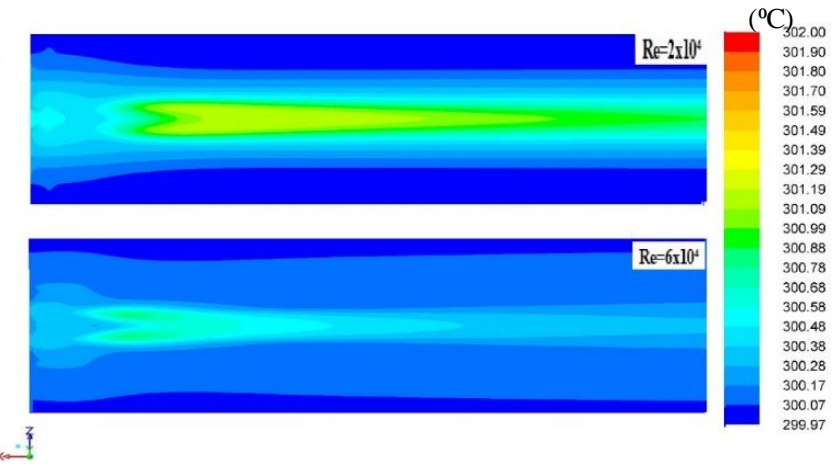

Gambar 15. Perbandingan visualisasi kontur temperatur dengan variasi Reynolds number pada posisi $\mathrm{y} / \mathrm{h}=1$ dan $\alpha=90^{\circ}$.

Gambar diambil pada plane $\mathrm{y} / \mathrm{h}=0,5$. Pada Gambar 13 terlihat adanya peningkatan temparatur di sepanjang sumbu z hingga di outline. Pada $\alpha=30^{\circ}$ terlihat bahwa kenaikan temperatur bisa mencapai $1,19^{\circ}$ C. Sedangkan pada sudut lainnya, gambar 14 dan 15 , kenaikan temperatur bisa mencapai $1,3^{\circ} \mathrm{C}$. Kemudian juga untuk area terjadinya kenaikan temperatur, area tersempit berada pada model dengan sudut $\alpha=30^{\circ}$. Semakin curam sudut inclined step maka semakin jauh dan luas area yang mengalami kenaikan temperatur.

\section{B. Panjang Reattachment}

Setelah dilakukan simulasi akan didapatkan gambaran mengenai pola aliran separasi yang jarak titik reattachment dengan step dapat diperkirakan dengan melihat vector lapis batas. Gambar 16 merupakan gambaran resirkulasi apabila terdapat penghalang aliran berupa gedung. Karena adanya penghalang di bagian upstream membuat aliran fluida terganggu dan menciptakan ruang yang lebih besar untuk terjadinya separasi sehingga titik separasi menjadi lebih dekat dari step.

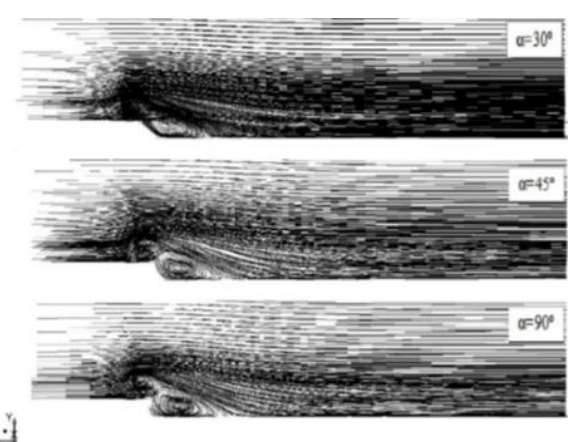

Gambar 16. Resirkulasi aliran dengan variasi sudut incined step pada posisi $\mathrm{x}=0,75\left(\operatorname{Re}=6 \times 10^{4}\right)$.

Gambar 16 diambil pada $\mathrm{x}=0.75$ atau saat aliran melewati tengah gedung. Selanjutnya panjang reattachment dapat terlihat pada tabel 2 .

Tabel 2.

Perbandingan panjang reattachment pada $\mathrm{Re}=6 \times 10^{4}$.

\begin{tabular}{cccc}
\hline \hline Variasi $\alpha$ & \multicolumn{3}{c}{ Variasi z/h } \\
\cline { 2 - 4 } & $\mathrm{X}=0$ & $\mathrm{X}=0,75$ & $\mathrm{X}=3$ \\
\hline $30^{0}$ & 5,762 & 4,534 & 5,1 \\
\hline $45^{0}$ & 6,504 & 5,321 & 5,667 \\
$90^{\circ}$ & 6,854 & 6,05 & 6,206 \\
\hline \hline
\end{tabular}

Perbedaan panjang reattachment dikarenakan step $\alpha=30^{\circ}$ memiliki ruang kosong yang lebih sempit dari pada step $\alpha=45^{\circ}$ dan step $\alpha=90^{\circ}$ sehingga ruang untuk terjadinya wake-pun lebih sempit. Hal ini juga terjadi pada aliran dengan $\mathrm{Re}=2 \times 10^{4}$ yang memiliki pola yang mirip. Perbedaan hanya terdapat pada panjang reattachment yang ditampilkan pada tabel 3 .

Tabel 3 .

Perbandingan panjang reattachment pada $\mathrm{Re}=2 \times 10^{4}$.

\begin{tabular}{cccc}
\hline \hline Variasi $\alpha$ & \multicolumn{3}{c}{ Variasi z/h } \\
\cline { 2 - 4 } & $\mathrm{X}=0$ & $\mathrm{X}=0,75$ & $\mathrm{X}=3$ \\
\hline $30^{\circ}$ & 5,186 & 4,459 & 10,7 \\
\hline $45^{\circ}$ & 5,67 & 5,01 & 10,8 \\
$90^{\circ}$ & 6,157 & 6,206 & 10,9 \\
\hline \hline
\end{tabular}

\section{Coefficient of Pressure $(\mathrm{Cp})$}

Coefficient of Pressure ( $C p$ ) merupakan salah satu bilangan nondimensional yang dapat mempresentasikan seberapa besar fluida menghasilkan tekanan tanpa tergantung kecepatan fluida.

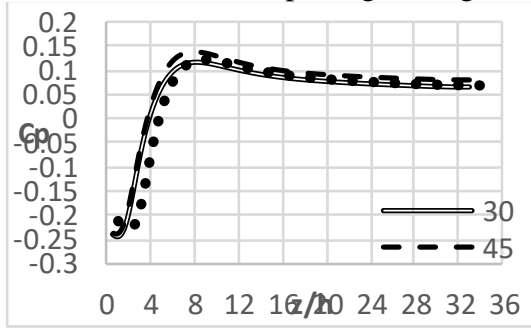

Gambar 17. Perbandingan grafik Cf darah downstream dengan variasi sudut inclined step pada $\mathrm{x} / \mathrm{h}=0,75\left(\mathrm{Re}=2 \times 10^{4}\right)$.

Dari Gambar 17 terlihat bentukgrafik yang sama. Pada posisi $\mathrm{x} / \mathrm{h}=0,75$, aliran fluida dari ketiga model pada mulanya akan mengalami percepatan yang ditandai dengan penurunan grafik akibat favorable pressure gradient. Setelah itu mengalami perlambatan yang ditandai dengan kenaikan sangat tajam diakibatkan oleh aliran yang tidak mampu melawan adverse pressure gradient pada saat penampang mengembang dengan tiba-tiba sehingga aliran terseparasi. Separasi akan berangsur normal dan akhirnya akan hilang, ini disebabkan karena adanya 
transfer energi antara aliran yang berada di daerah yang tidak terseparasi menuju aliran yang berada didaerah terseparasi sehingga aliran yang terseparasi akan berangsur-angsur kembali normal. Pengambilan data diambil pada bagian downstream area dan terletak perhimpit pada dinding bawah. Karena nilai $\mathrm{cp}$ tidak bergantung terhadap ukuran maupun kecepatan fluida maka hasil pengambilan data pada $\operatorname{Re}=6 \times 10^{4}$ akan menghasilkan grafik $\mathrm{Cp}$ yang sama persis dengan garfik $\operatorname{Re}=2 \times 10^{4}$. Hal tersebut dikarenakan kedua variasi kecepatan menggunakan bentuk domain yang sama.

Dari grafik terlihat bahwa adanya variasi sudut inclined step berpengaruh terhadap tekanan statis. Dari ketiga variasi sudut step terlihat bahwa model yang memiliki $\alpha=30^{\circ}$ dan $\alpha=45^{\circ}$ memiliki grafik yang nyaris berhimpitan. Setelah terjadi percepatan, domain dengan $\alpha=30^{\circ}$ dan $\alpha=45^{\circ}$ memiliki percepatan yang lebih tinggi dari pada $\alpha=90^{\circ}$. Hal ini karena kemiringan step membuat lintasan lebih sempit sehingga nilai cp lebih rendah dan terjadi percepatan yang lebih tinggi.

\section{Coefficient of Friction ( $C f$ )}

Sama seperti coefficient of pressure $(\mathrm{Cp})$, coefficient of friction $(C f)$ merupakan parameter nondimensional. Dengan kata lain besarnya Cf tidak terpengaruh oleh kecepatan fluida. Besarnya skin friction coefficient $(\mathrm{Cf})$ erat kaitannya dengan besarnya tegangan geser dinding $(\tau \omega)$. Geometri backward facing step identik dengan perubahan penampang yang melebar sehingga aliran yang mengalir didalamnya akan memperoleh pengaruh dari adverse pressure gradient yang besar.

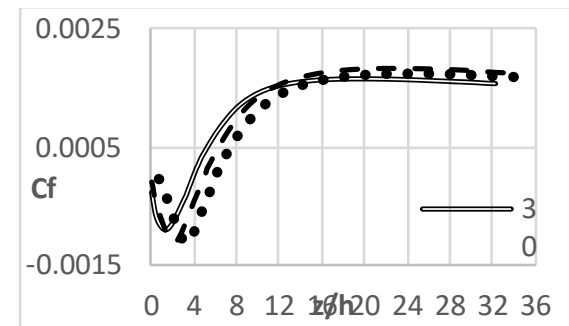

Gambar 18. Perbandingan grafik $\mathrm{Cf}$ daerah downstream dengan variasi sudut inclined step pada $\mathrm{x} / \mathrm{h}=0,75\left(\mathrm{Re}=2 \times 10^{4}\right)$.

Turunnya nilai Cf dimulai dari nol mengindikasikan terjadinya separasi aliran yang dipengaruhi adverse pressure gradient sehingga terjadi penebalan boundarylayer, akibatnya aliran didekat diverging wall akan mengalami defisit momentum sehingga terjadi separasi. Kemudian berangsurangsur kecepatan aliran kembali normal diikuti oleh kenaikan nilai Cf. Gambar 18 menunjukan grafik $\mathrm{Cp}$ pada daerah downstream yang diukur dari step hingga ke outlet. Dari grafik Cf didapatkan bahwa nilai panjang reattachment yang paling kecil berada di plane $\mathrm{x}=0$ dengan nilainya adalah 4 pada sudut $\alpha=30^{\circ}$ dan nilai reattachment yang paling besaryaitu pada jarak sudut $\alpha=90^{\circ}$ dengan nilainya adalah 6,5 .

\section{KESIMPULAN/RINGKASAN}

Berdasarkan berbagai analisa, kecepatan, temperatur, Reattachment, $C p$, dan Cf, setiap variasi inclined step memiliki pengaruh yang berbeda. Grafik dan kontur kecepatan memperlihatkan semakin sempit sudut inclined step makan semakin sempit pula area terjadi backflow pada adaerah downstream. Grafik dan kontur temperatur memperlihatkan, baik $\operatorname{Re}=2 \times 10^{4}$ maupun $\operatorname{Re}=6 \times 10^{4}$, pada step $\alpha=90^{\circ}$ terjadi kenaikan temperatur yang spesifik hingga mencapai outlet. Hal ini karena area wake yang lebih luas dan lambatnya kecepatan fluida sehingga penumpukan fluida panas yang juga lebih banyak pada daerah downstream. Mempertimbangkan hasil simulasi, pembangunan pada daerah downstream sebaiknya dilakukan pada derah yang memiliki sudut inclined step kecil.atau landai. Pembangunan juga bisa dilakukan tidak berada tepat dibawah bangunan yang mengeluarkan fluida dengan tempsaratur tinggi. Selain itu, simulasi dengan variasi jarak gedung pada sisi upstream dengan step atau jarak antar gedung diperlukan untuk mendapat gambaran fenomena pada kondisi yang lain.

\section{DAFTAR PUSTAKA}

[1] Y. Toparlar and et al, Renewable and Sustainable Energy Reviews. Netherlands: Eindhoven University of Technology, 2017.

[2] L. Biao, "Evaluation of CFD Simulation Using Various Turbulence Models for Wind Pressure on Buildings Based on Wind Tunnel Experiments,"China, 2015.

[3] P. Louda, "Numerical Simulation of Flows Over 2D and 3D Backward-Facing Inclined Steps," Czech Republic, 2013. 